Research Report No. 62/2013

\title{
What Lies Before, Behind and Beneath a Case? Five Minutes on Transnational Lawyering and the Consequences for Legal Education
}

Peer Zumbansen

Osgoode Hall Law School of York University, PZumbansen@osgoode.yorku.ca

Follow this and additional works at: http:// digitalcommons.osgoode.yorku.ca/clpe

\section{Recommended Citation}

Zumbansen, Peer, "What Lies Before, Behind and Beneath a Case? Five Minutes on Transnational Lawyering and the Consequences for Legal Education" (2013). Comparative Research in Law \& Political Economy. Research Paper No. 62/2013.

http://digitalcommons.osgoode.yorku.ca/clpe/304 


\section{OSGOODE}

OSGOODE HALL LAW SCHOOL

YOR K UNIVERSITY

\section{OSGOODE HALL LAW SCHOOL}

Comparative Research in Law \& Political Economy

RESEARCH PAPER SERIES

Research Paper No. 62/2013

What lies Before, Behind and Beneath a Case? Five Minutes on Transnational Lawyering and the Consequences for Legal Education

Peer Zumbansen

Editors:

Peer Zumbansen (Osgoode Hall Law School, Toronto, Director Comparative Research in Law and Political Economy)

John W. Cioffi (University of California at Riverside)

Comparative Research in Law \& Political Economy 


\title{
What lies Before, Behind and Beneath a Case? Five Minutes on Transnational Lawyering and the Consequences for Legal Education
}

\author{
Peer Zumbansen
}

\begin{abstract}
:
The following paper serves as the Epilogue to an edited volume that celebrates the first decade of McGill's ambitious legal education reform in 'Transsystemic Law'. Placing this innovation in a larger context of curriculum reform, law school crisis - then and now -, it becomes apparent that McGill's program can be seen as part of global changes in the way that law schools struggle with student expectations, market demands, and shifting frameworks of domestic and transnational lawyering. Karl Llewellyn's observations "On What is Wrong With Legal Education" ring true still today, almost eighty years later. Still we seek ways to inspire law students to think critically and to develop a sense for their own moral compass, and still we find ourselves succumbing to the pressure to deliver, above all, "skills" and practical training. The here made contention is to introduce transnational case scenarios, constellations and case studies into the law school curriculum to illustrate the complexity of social and legal facts and the treacherousness of forgetting the former over an exclusive emphasis on the latter: using, for example, labor rights struggles as in the context of the Foxconn suicides or in the Bangladeshi ready-made-garment industry, we can introduce students to different layers of legal, political and social arguments in contexts where it is not enough to identify plaintiff and defendant. The "case" beneath that case is infinitely more complex and necessitates historical, political, economic, cultural understanding. Confronting students in first and upper year classes with such instances of 'law in context', we might begin to complement our already ongoing efforts of making them sensitive to the ethical challenges of legal profession with accessible examples of transnational lawyering. Such illustrations bear crucial insights into the transnational complexities of rights advocacy, lawyering, access to justice and the legal process.
\end{abstract}

Keywords: legal education, law school crisis, transnational lawyering, ethical lawyering, access to justice, transnational advocacy networks, legal process, law in context, transnational law, legal pluralism.

Forthcoming in: Shauna Van Praagh and Helge Dedek (eds.), Stateless Law: Evolving Boundaries of a Discipline (Ashgate, 2014). 


\title{
What lies Before, Behind and Beneath a Case? Five Minutes on Transnational Lawyering and the Consequences for Legal Education*
}

\author{
PeER Zumbansen*
}

Caveat.

I am, of course, borrowing title and ambition from Gustav Radbruch. ${ }^{1}$ The Social Democratic politician and legal philosopher was born in 1878 and served as Justice Minister during the early years of the Weimar Republic. He died in 1949. The "Five Minutes" premedidate and capture the gist of his famous 1946 essay $^{2}$, in which he observed that the Nazi judiciary had been rendered "defenceless" by Legal Positivism. He went on to state that the discrepancy however between Nazi "law" and the law that would be built on "Zweckmäßigkeit" (expediency) and"Gerechtigkeit" (justice) action had been so significant that the former could not have been "law at all". In his 1945 sketch for the Newspaper, we find this idea expressed already in succinct form, delivered in five short paragraphs. The first paragraph minute states that both for soldiers and lawyers/judges the formula was that orders had to be obeyed, but in law it would be required of the judge to evaluate whether there is an unbearable discrepancy between what is the "law" and what "ought" to tbe the law in light of considerations of expediency and justice. Minute 2 was devoted to the pronouncement that not all would count as "law" which serves the people, but only what "is" law serves the people. In Minute 3 he stated that law had to strive for justice which meant that it must be committed to the respect for the individual and strive for equal protection for all. The next Minute, 4, is crucial as Radbruch here addresses the final element to accompany expediency and justice. That element - legal certainty - however, can of course be central to any authoritarian or non-authoritarian rule of law: in response to the concept's attractive elusiveness and instrumentalizability, ${ }^{3}$ Radbruch formulates the phrase later famously endorsed in the Lawlessness essay: legal certainty has to back down where the gap between

\footnotetext{
* This paper builds on the remarks offered at the STATELESS LAW conference at the Faculty of Law at McGill University on XX September 2012, celebrating the 10th Anniversary of the Transsystemic Law Program. I am grateful to Dean Daniel Jutras as well as to Professors Lionel Smith, Shauna Van Praagh and Helge Dedek for the invitation to contribute to this memorable meeting and to Simon Archer, Helge Dedek, Priya Gupta, Alexandra Kemmerer and Hengameh Saberi for their valuable feedback.

*Professor of Law and Canada Research Chair, Osgoode Hall Law School, Toronto. Email: Pzumbansen@osgoode.yorku.ca

1 "Fünf Minuten Rechtsphilosophie", published on September 12, 1945 in the daily newspaper RHEIN-NECKARZEITUNG.

2 "Gesetzliches Recht und übergesetzliches Unrecht", (1946) Süddeutsche Juristenzeitung, 105-108 ("Statutory Lawlessness and Supra-Statutory Law" - St. Paulson transl., republished in (2006) 26:1 Oxford Journal of Legal Studies, 1-11.

${ }^{3}$ See A. Santos, 'The World Bank's Uses of the 'Rule of Law' Promise in Economic Development', in D. Trubek and A. Santos (eds), The New Law and Economic Development. A Critical Appraisal (Cambridge University Press, 2006), 253-300.
} 
the law and what we think law must be, becomes unbearably wide. In the fifth Minute, he provides us with the justificatory basis on which to evaluate and bridge the gap: referring to a core content of natural law, as it evolved over the course of centuries, Radbruch suggests that it is God's law that will ultimately strike the balance.

I am afraid, that my own five minutes for this epilogue at the end of an inspiring volume on the theme of "stateless law" and transsystemic legal education at the occasion of McGill's Faculty of Law's 10th anniversary celebration of its Transsystemic Law program are already over and all that was achieved was to invoke a seminal legal philosophical intervention. And, now that my five minutes are over before I could even begin to explain the connection between Radbruch and Transsystemia, please allow me another five minutes to justify this act of disobiedience.

\section{Transsystemia}

McGill's program notably bridges the idiosyncracies and particularities of civil and common law by instructing students in a combination of principles and concepts borrowed from either legal culture. In that process, much more happens than merely another attempt to think about what keeps civil and common law apart or what connects both. Regardless of how committed the program instructors might or might not be on keeping the Civ-Com-Law comparison at the heart of their training, the enterprise inevitably exposes students to the much larger conceptual as well as real challenges arising from an engagement with law on the basis that it has multiple foundations as well as historical evolutionary trajectories - the bottom halves of the icebergs of the grand system and theory clashes in law, as McGill Patrick Glenn once called them. ${ }^{4}$ Because, once notions of context and evolution begin to enter the imagination, it becomes one thing to state that the transsystemic orientation is centered around civil and common law - it becomes quite another to keep it that way. As students learn about the origins, character traits and modes of development of each, they are becoming increasingly aware of how laws are products ${ }^{5}$ that can only be understood from within a particular context in which they are understood, accepted and employed as law or, as the case may be, rejected as other-than-law, non-law, unjust-law. Meanwhile, the words, terms and categories are but attempts to give expression to the different meanings of law, a process that must always remain tentative, experimentalist. ${ }^{6}$

\footnotetext{
${ }^{4}$ H. P. Glenn, 'Doin' the Transsystemic: Legal Systems and Legal Traditions', (2005) 50 McGill Law Journal 863$898,867$.

${ }^{5}$ M. Villey, Leçons d'histoire de la philosophie du droit, rev. éd. (Paris: Dalloz, 1962, 202, cited in Glenn, above note 4, 870: "...le juriste défend une cause. Décrire pour lui c'est choisir."

${ }^{6}$ D. Jutras, 'Énoncer l'indicible: le droit entre langue et traditions', (2000) 52 Revue internationale de droit comparé $781-796,795:$ “... on peut [... ] dire que les réprésentations propres à chaque tradition constituent autant de tentatives d'exprimer une normativité souterraine et indicible, une normativité implicite, sinon immanente aux rapports sociaux, qui déborde les cultures juridiques nationales."
} 
As this engagement with law's mind and matter informs the design and implementation of the law school's ambitious legal education program, a crucial insight the students can gain already at the beginning of their training in how to both understand and navigate the boundaries between civil and common law, is that there is more of what the two legal cultures have in common than what separates them. From that perspective, the boundaries between the two cultures begin to appear in a different light. They now are becoming explainable against particular historical data, concrete contexts and instances as well as institutional and political roads taken. At the same time, students begin to appreciate how the distinction between civil and common law to the degree that it aims to capture enduring differences in character and nature are perhaps more a matter of convention and discursive practice than actually grounded in the ongoing practice of either. Namely, common law's core feature, that is the commitment to and the central role played by adjudication, can relatively easily be found all across so-called civil law systems. We could add further elements to illustrate the ultimate elusiveness of the purported boundaries between the two legal cultures, but that is not even necessary. More important for our present purposes is to take one step back and look at the context in which this discussion is taking place today. It is this context I am most interested in when I reflect on the immense merits and promises of a program such as McGill's.

A few keywords stand out which appear to sketch the contours as well some of the structural features of this context. The increasing proliferation of non-state actors involved in the preparation and collaboration in or even the solely responsible production of norms has been a central feature of the modern Western welfare state throughout the course of the late Twentieth Century. ${ }^{7}$ This devolution of norm creation from the state to a wide range of societal actors has prompted everything from doomsday pronouncements regarding the decline of public authority to Carl Schmitt's lament over the Levaithan being cut up and devoured by society ${ }^{8}$ to triumphant claims that the welfare state was an erroneous path, ${ }^{9}$ from which only the embrace of societal self-regulation, "social norms" and a rejection of an interventionist state. ${ }^{10}$ Somewhere in between this conceptual and real, institutional and procedural turf war, ideas of adapting law to these changing circumstances: in the names of

\footnotetext{
${ }^{7}$ C. Scott, 'Private Regulation of the Public Sector: A Neglected Facet of Contemporary Governance', (2002) 29 Journal of Law and Society 56-76; B. Morgan/K. Yeung, An Introduction to Law and Regulation. Texts and Materials (Cambridge University Press, 2007).

${ }^{8} \mathrm{C}$. Schmitt, 'State Ethics and the Pluralist State (orig. published in German as 'Staatsethik und pluralistischer Staat', in Schmitt, Positionen und Begriffe im Kampf mit Weimar - Genf - Versailles 1923-1939, Berlin: Duncker \& Humblot 1988 [1940], 133-145)', in A. J. Jacobson and B. Schlink (eds), Weimar. A Jurisprudence of Crisis (University of California Press, 1930), 300-312.

${ }^{9}$ F. A. Hayek, The Mirage of Social Justice [Law, Legislation and Liberty. A new statement of the liberal principles of justice and political economy, vol. 2] (The University of Chicago Press, 1976). This claim just repeats itself: see, e.g., C. Hoffmann/P. Bessard, Sackgasse Sozialstaat. Alternativen zu einem Irrweg (Liberales Institut, 2011).

${ }^{10}$ See the critical takes by two who know: R. C. Ellickson, 'Law and Economics Discovers Social Norms', (1998) 27 Journal of Legal Studies 537-565, and S. Macaulay, 'Relational Contracts Floating on a Sea of Custom? Thoughts about the Ideas of Ian Macneil and Lisa Bernstein', (2000) 94 Northwestern University Law Review 775-804.
} 
responsive ${ }^{11}$ and reflexive, ${ }^{12}$ even learning ${ }^{13}$ law, scholars sought to capture the essence of law as an instrument of people's egalitarian self-government in a context in which the welfare state's capacity to develop and deliver social safeguards had started to become precarious, both financially and conceptually. This "exhaustion" of the Welfare State, as Jürgen Habermas called it, ${ }^{14}$ resulted in a normative and institutional ambiguity that indeed encapsulates much of the structure we are confronted with in our present-day transnational constellation. ${ }^{15}$ The "legal pluralism" of global legal cultures is referred to in empiricalsociological ${ }^{16}$ as well as normative-philosophical ${ }^{17}$ ways. The diffusion of norm creation processes through "hard" forms such as treaties and laws to more "soft" forms including conventions, codes, guidelines to even more elusive, possibly out-of-legal-bounds norms such as recommendations, suggestions, public relations statements illustrates the richness of a regulatory wonderland, but the politics of it all remain, well, all over the place. Who counts as competent actor in this hybrid, pluralistic norm-creation universe? The individual or organization with the expertise, competence and most adequate understanding of the problem at hand? Or, he, she who is authorized to deliver (and, enforce) binding norms of law? The transnational regulatory landscape is above all characterized by an intriguing, if often bewildering side-by-side and interaction among Actors, Norms and Processes. ${ }^{18}$ What are we to make of these terms? Do they constitute 'new' categories of 'old', Western Welfare State institutional-conceptual frameworks such as the Rule of Law, Separation of Powers, normative hierarchy and unity of law, or are they bloodless word-phrases, loosely attached to the madness of global un-law with a piece of gum?

\section{Reality Bites}

We are not making any of this up. Read Jack Goldsmith's poignant reminder of what is at stake when, in what could have been the eve of a U.S.-led attack on Syria, the legally entirely ambiguous "precedent" of the Nato bombing of Serbia 1999 is used to justify the "enforcement" of "international norms" through unilateral military action. ${ }^{19}$ How much

\footnotetext{
${ }^{11}$ G. Teubner, 'Substantive and Reflexive Elements in Modern Law', (1983) 17 Law \& Society Review $239-285$.

${ }^{12}$ P. Nonet/P. Selznick, Law and Society in Transition. Toward Responsive Law (Octagon Books, 1978).

${ }^{13} \mathrm{C}$. F. Sabel/J. Zeitlin, 'Learning from Difference: The New Architecture of Experimentalist Governance in the EU', (2008) 14 European Law Journal 271-327; P. Zumbansen, 'Law's Effectiveness and Law's Knowledge: Reflections from Legal Sociology and Legal Theory', (2009) 10 German Law Journal 417-438.

${ }^{14} \mathrm{~J}$. Habermas, 'The New Obscurity: The Crisis of the Welfare State and the Exhaustion of Utopian Energies [1985]', in J. Habermas (ed) The New Conservatism. Cultural Criticism and the Historians' Debate [ed. and transl. by Shierry Weber Nicholsen] (MIT Press, 1989), 48-70.

${ }^{15}$ See, e.g., K. W. Abbott/D. Snidal, 'Strengthening International Regulation Through Transnational New Governance: Overcoming the Orchestration Deficit', (2009) 42 Vanderbilt Journal of Transnational Law $501-578$.

${ }^{16}$ R. A. MacDonald/J. MacLean, 'No Toilets in Park', (2005) 50 McGill Law Journal 721-787; B. d. Sousa Santos, 'Law: A Map of Misreading. Toward a Postmodern Conception of Law', (1987) 14 Journal of Law \& Society 279302.

${ }^{17}$ N. Kasirer, 'Lex-icographie mercatoria', (1999) 47 American Journal of Comparative Law 653-676;

${ }^{18}$ P. Zumbansen, 'Transnational Private Regulatory Governance: Ambiguities of Public Authority and Private Power', (2013) 76 Law \& Contemporary Problems http://ssrn.com/abstract=2252208

19 J.Goldsmith, What Happened to the Rule of Law?, NEW YORK TIMES, 31 August 2013, http://www.nytimes.com/2013/08/31/opinion/what-happened-to-the-rule-of-law.html?hp\&_r=1\&
} 
would our public international law students learn if we engaged them in this turmoil over what is and what isn't, what should and what shouldn't be a precedent? ${ }^{20}$

Maybe, then, all we can do is to learn as we go along. Just as JM Keynes both recognized and cautioned against the human tendency to read yesterday's numbers to predict their magnitude today, ${ }^{21}$ we often hopelessly use legal history and doctrine to write lines in the sand. ${ }^{22}$ Instead, what we want to do, and what Radbruch intentioned, is making connections, for example between present experiences of crisis and loss of bearings and the past and present of human conventions, of instances of consensus and pronouncement, that themselves grew out of hard-fought-for-and-over processes of deliberation. ${ }^{23}$ We have long learned that the legitimacy of such processes not only depends on Radbruch's and our capacity to hear Him but to question the boundaries and scope of the "we". ${ }^{24}$ In other words, questions of belonging, membership, integration are central to the reflection on a legal system the institutional foundations have become so diffused. ${ }^{25}$ Connected to these must be the awareness of the ongoing and effective processes of exclusion, demarcation and devaluation. ${ }^{26}$ One's terrorist is another's freedom fighter. Precedent, in law, is caught up in legal narrative. That narrative, the reconstruction of meaning along what becomes a "line of cases", is always embedded, as the Kosovo-as-precedent example illustrates, in an infinite number of alternative narratives. We are only too aware of this in any instance of legal interpretation ${ }^{27}$ as well as in our identification of normativity. ${ }^{28}$ The true challenge for lawyers is the conscious navigation of the space between the case that's before the court and the "cases" behind, underneath that case.

Looking at this, we open our curriculum catalogues and course programs and wonder. What is it that we are doing? What should lawyers study today? Why are we both constantly

\footnotetext{
${ }^{20}$ The background can easily be discerned here: M. Koskenniemi, "The Lady Doth Protest Too Much'. Kosovo, and the Turn to Ethics in International Law', (2002) 65 Modern Law Review 159-175, A. Orford, 'Muscular Humanitarianism: Reading the Narratives of the New Interventionism', (2003) 10 Eur. J. Int'I L. 679-711, and A. L. Paulus, 'The War Against Iraq and the Future of International Law: Hegemony or Pluralism?', (2004) 25 Michigan Journal of International Law 691. For an insightful engagement with precedent, see F. Schauer, 'Precedent', in: A. Marmor (ed.), Routledge Companion to the Philosophy of Law (Routledge: New York, 2012), available at: http://ssrn.com/abstract=1836384.

${ }^{21}$ JM Keynes, General Theory of Employment, Interest and Money (Harcourt, Brace \& Co.: New York, 1936), ch. 12.

${ }^{22}$ R. J. Shiller, Irrational Exuberance, 2nd ed. (Currency Doubleday, 2005); G. A. Akerlof/R. J. Shiller, Animal Spirits. How Human Psychology Drives the Economy, and Why It Matters for Global Capitalism (Princeton University Press, 2009).

${ }^{23}$ P. Pierson, Politics in Time. History, Institutions, and Social Analysis (Princeton University Press, 2004).

${ }^{24}$ B. d. Sousa Santos, 'Beyond Abyssal Thinking. From global lines to ecologies of knowledge', (2007) Eurozine http://www.eurozine.com/articles/2007-06-29-santos-en.html.

${ }^{25}$ S. Benhabib, The Rights of Others. Aliens, Residents and Citizens (Cambridge University Press, 2004).

${ }^{26}$ R. MacDonald, 'Whose Access? Which Justice?', (1992) 7 Canadian Journal of Law \& Society 175.

${ }^{27}$ R. M. Cover, 'Nomos and Narrative', (1983) 97 Harvard Law Review 4-68.

${ }^{28}$ S. F. Moore, 'Law and Social Change: the semi-autonomous field as an appropriate subject of study', (1973) 7 Law \& Society Review 719-746; D. R. Holmes/G. E. Marcus, 'Cultures of Expertise and the Management of Globalization: Toward the Refunctioning of Ethnography', in A. Ong and S. J. Collier (eds), Global Assemblages: Technology, Politics, and Ethics as Anthropological Problems (Blackwell, 2005), $235-252$.
} 
disturbed and intrigued by calls for introducing more Business School-like "case studies" in legal education? ${ }^{29}$ Maybe, our skepticism has its roots in a stubborn insistence on law's embeddedness in a long history that is, above all, a trove of discursive and political struggles over the very meaning of the words which are traded on today's market of attention. The awareness of this history and background leads to Hercules" humility and aspiration to "get it right". ${ }^{30}$ Meanwhile, why not "teach" Goldsmith's op-ed ${ }^{31}$ rather than Simma's and Cassese's stand-off in European Journal of International Law in 1999 ? $^{32}$ How to combine the accessibility, sharpness and in-the-midst-of-it-all nature of the op-ed with the formidably rich yet succinct restatements of legality as the ultimate boundary on the one hand (Simma) and legitimacy as the necessary herald of a new legality (Cassese)?

\section{The "Cases" behind, underneath and before the Case}

Verba docent, exempla trahunt. Rather than teaching law from Abraham, Raskalnikov or HLA Hart, why not read the news? Why not confront students with the reality and complexity of the 'cases' unfolding right before our eyes? Why not try to facilitate students to discern the 'legal aspects' of stories reported by the media, stories that centrally implicate competing visions of justice, human rights and social order?

September 2007: The Canadian Federal government begins to implement the "Indian Residential Schools Settlement Agreement". ${ }^{33}$ The IRSSA had been concluded the previous year following an inherently troubled alternative dispute resolution process, eventually launched, after earlier attempts, in 2003. Beyond establishing a system to determine eligibility and to distribute pro-rated, financial compensations to former students of the Canadian Indian Residential Schools system, the Settlement further resulted in the institutionalization of the Indian Residential Schools Truth and Reconciliation Commission. Launched in 2008, it is expected that the TRC will conclude its work in 2014. The Canadian Prime Minister, Stephen Harper, publicly issued an Apology ${ }^{34}$ on the part of the Canadian state for the role that the government had played in the establishment and administration of the residential schools. What is the significance of the settlement, the approval, the apology, the commission ${ }^{35}$

\footnotetext{
${ }^{29}$ http://www.law.harvard.edu/academics/degrees/jd/pos/law-and-bus/ (Accessed 21 November 2013)

${ }^{30}$ R. Dworkin, Law's Empire (Harvard University Press, 1986).

${ }^{31}$ Above, note 19.

32 B. Simma, 'NATO, the UN and the Use of Force: Legal Aspects', (1999) 10 European Journal of International Law 1-22; A. Cassese, 'Ex inuiria ius oritur: Are We Moving towards International Legitimation of Forcible Humanitarian Countermeasures in the World Community?', (1999) 10 European Journal of International Law 2330.

${ }^{33}$ http://www.residentialschoolsettlement.ca/english.html (accessed 21 November 2013). The caption on the homepage reads "The residential schools settlement has been approved. The healing continues."

${ }^{34}$ Rt. Hon. Stephen Harper, Statement of Apology - to former students of Indian Residential Schools, 11 June 2008, http://www.aadnc-aandc.gc.ca/eng/1100100015644/1100100015649 (accessed 21 November 2013).

${ }^{35}$ M. Laing, 'An Analysis of Canada's Indian Residential Schools Truth and Reconciliation Commission' (2013) 4:1 Undergraduate Transitional Justice Review 34; D.B. MacDonald \& G. Hudson, 'The Genocide Question and Indian
} 
November 2011: The German Federal Administrative Court upholds a ban on muslim prayers performed in a public (Berlin) high school during break-hours with reference to the need to protect peace and order in the school. ${ }^{36} \mathrm{~A}$ group of muslim adolescents had, in a relatively removed part of the school, performed muslim ritual prayers, a practice that the school board had declared impermissible. After the first instance court had struck down this ban, ${ }^{37}$ the respondents eventually saw the highest administrative court side with the school's administration. Arguing that the constitutional guarantee of religious freedom, as protected under the German Grundgesetz (constitution) found their limits in the right of the state to maintain a secular, non-discriminatory space of public education, the Court sparked a wideranging debate over the exercise of religious rights in public spaces. ${ }^{38}$

May 2012: A German district court recognizes criminal battery in the case of a medical practitioner who, two years prior, had performed a male circumcision on a 4-year old muslim with parental consent. ${ }^{39}$ An outcry across a range of religious as well as secular organizations, interest groups and activists follows this decision. Ten months later, the German federal government passes a law explicitly legalizing male circumcision. ${ }^{40}$ Polls show that $70 \%$ of the public disagrees with this legislation.

February 2013: Following a wave of protests, riots, unofficial strikes as well as numerous worker suicides among the 1,2 million employees of the Taiwan based Apple products manufacturing company Foxconn in China, Apple announces that it will allow the periodical election of union representatives for Foxconn employees. Despite a broad concern with worker conditions at the factories of this global brand company, the unionization news are met with considerable skepticism. ${ }^{41}$ Critique is levelled against the questionable election processes and the asymmetric power distribution between management and employees within the union.

\footnotetext{
Residential Schools in Canada' (2012) 45:2 Canadian Journal of Political Science 427; see already J. Llewellyn, 'Dealing with the Legacy of Native Residential School Abuse in Canada: Litigation, ADR, and Restorative Justice' (2002) 52 University of Toronto Law Journal 253.

${ }^{36}$ German Federal Administrative Court (Bundesverwaltungsgericht), Decision of 30 November 2011 [BVerwG 6 C 20.10]; see the commentary by H.Rubin, 'Das islamische Gebet in der Schule - Bespr. von BVerwG v. 30.11.2011, (2012) JURA, 718-722.

37 Administrative Court Berlin (Verwaltungsgericht), Decision of 29 September 2009 [3 A 394.07].

${ }^{38}$ See, e.g., http://english.alarabiya.net/articles/2011/11/30/180140.html (accessed 21 November 2013).

${ }^{39}$ Regional Court (Landgericht) Cologne, Judgement of 7 May 2012 [151 Ns 169/11], published in: (2012) Neue Juristische Wochenschrift), 2128; see, hereto, the essay by Bijan Fateh-Moghadam, 'Criminalizing male circumcision? Case Note: Landgericht Cologne, Judgment of 7 May 2012 - No. 151 Ns 169/11', (2012) 13:9 German Law Journal, 1131-1145.

${ }^{40}$ http://www.bundestag.de/dokumente/textarchiv/2012/42042381_kw50_de_beschneidung/ (accessed 21 November 2013).

${ }^{41}$ http://www.mirova.com/Content/Documents/Mirova/publications/va/focus/MIROVA_FOCUS Foxconn\%2olabour\%2ounion\%20elections.pdf (accessed 21 November 2013)
} 
April 2013: The U.S. Supreme Court rules in the case brought by a group of Nigerian human rights groups and activists that the 1789 Alien Tort Statute does not provide a substantive claim in cases of alleged human rights violations by multinationals in foreign jurisdictions. The Kiobel decision ${ }^{42}$ follows on a string of related cases all concerned with the justiciability of egregious rights violations by corporations, often colluding with paramilitaries or other host country officials towards company employees and other segments of the local population. ${ }^{43}$ The decision is received with great disappointment, as the ATS had become a promising, if always ambiguous vehicle not only to litigate such cases, but also to bring the underlying facts to a wider, Western public attention. ${ }^{44}$

June 2013: the U.S. Supreme Court delivers two much anticipated same sex marriage decisions. For many years already, this issue has been on the minds of lawmakers, activists and the general public in many countries around the world. Especially the Court's much anticipated decision in United States $v$. Windsor ${ }^{45}$ is, despite competing - including, transnational ${ }^{46}$ - interpretations of the judgment's consequences, generally seen as a significant step in the evolution of the law in this area. Domestically, the public policy debate surrounding and following the Supreme Court's verdict goes private: In the midst of this ongoing conversation about "horizontal effect", governmental "intervention" and corporate social responsibility, Wal-Mart, with 1,2m U.S. employees the country's biggest private sector employer, announces that it will with immediate effect extend the company's health care benefits to same-sex partners of members of its workforce. ${ }^{47}$ Directly following this news, labor side as well as LGBT representatives lament that in reality a large number of Wal-Mart employees cannot afford to contract into the company's health care plan in the first place. ${ }^{48}$

\footnotetext{
${ }^{42}$ Kiobel v. Royal Dutch Petroleum Co., 133 S. Ct. 1659, 185 L. Ed. 2 d 671 (2013).

${ }^{43}$ O. Murray/D. Kinley/C. Pitts, 'Exaggerated Rumours of a Death of an Alien Tort? Corporations, Human Rights, and the Remarkable Case of Kiobel', (2011) 12 Melbourne Journal of International Law 57-94;

${ }^{44}$ Center for Justice and Accountability: Kiobel v. Shell - Light Dims on Human Rights Claims in the U.S., http://cja.org/section.php?id=510 (accessed 21 November 2013); see also Susan Bisom-Rapp, 'The Irony of the Surpeme Court's Decision in Kiobel v. Royal Dutch Petroleum', (2013) laborprof_blog, 18 April 2013, http://lawprofessors.typepad.com/laborprof_blog/2013/04/the-irony-of-the-supreme-courts-decision-in-kiobelv-royal-dutch-petroleum.html (accessed 21 November 2013).

45570 U.S.__ (2013): http://www.supremecourt.gov/opinions/12pdf/12-307_6j37.pdf (accessed 21 November 2013).

${ }^{46}$ http://polityinindia.wordpress.com/2013/07/og/acaseforsamesexmarriages/; see also Reecha Daz, 'Constitutional Principles in US v Windsor in the Indian Context', Centre for Law \& Policy Research, 23 July 2013 , http://clpr.org.in/windsor/ (accessed 21 November 2013), discussing the significance of the US Supreme Court's ruling in the Indian context after the 2009 Delhi High Court judgment in the Naz Foundation case, which legalized homosexuality.

${ }^{47}$ http://www.thedailybeast.com/articles/2013/08/29/walmart-s-new-embrace-of-gay-employees-a-sign-ofcorporate-shift.html (accessed 21 November 2013).

${ }^{48}$ http://www.dailyfinance.com/on/walmart-offer-benefits-same-sex-partners-leaked-memo/ (accessed 21 November 2013).
} 
Question: Should law students learn how to address cases such as those anecdotally rendered here? If the answer were "yes", the following question would be how to teach students the "law" of these "cases".

Assumption: Sometimes, as with Foxconn or, even more recently, the long-brooding struggle over labor and human rights for the Bangladeshi ready-made-garment industry, ${ }^{49}$ some of these cases are not "cases" yet and hence there is no perhaps no easy way to include them in the curriculum. 'Skill training', clinical legal education ${ }^{50}$, 'experiential learning'51 - all these are but the tips of an iceberg, representing deeper disputes over the aims of legal education, the roles of lawyers in a changing, transnationalizing ${ }^{52}$ society and a precarisation of employment and long-term security. ${ }^{53}$ The task of reforming legal education, thus regarded, becomes an exercise in reflection upon the nature of legal knowledge ${ }^{54}$ and the scope of ethical and political responsibility of lawyers. ${ }^{55}$

Association: Take the example of the Canadian Residential Schools Settlement. What is the legal "field" the different dimensions of this 'case' would best be addressed in? To make this line of inquiry even more poignant: which course at a law school would likely include a session on the Settlement for its students? Is the IRSSA a (Canadian) example of an increasingly transnational concern with so-called Transitional Justice ${ }^{56}$ If so, what are the lessons of the IRSSA for law students? How and in which course should they learn about the procedural intricacies, the access to justice challenges and the law and reconciliation

\footnotetext{
49 See, e.g., Edward Bearnot, 'Bangladesh: A Labor Paradox', The World Policy Institute, 2 May 2013 “Join the Conversation”, http://www.worldpolicy.org/journal/fall2013/Bangladesh-Labor-Paradox (accessed 21 November 2013).

${ }^{50}$ Nadia Chiesa, 'The Five Lessons I learned Through Clinical Legal Education', (2009) 10:7 German Law Journal, 1113-1124, online at: http://germanlawjournal.com/pdfs/Vol10No07/PDF_Vol_10_No_07_SI_1113-1126_Chiesa.pdf; Richard Wilson, 'Western Europe: Last Holdout in the Worldwide Accēptance of Clinical Légal Education', (2009) 10:7 German Law Journal, 823-846, online at: http://germanlawjournal.com/pdfs/Vol10No07/PDF Vol 10 No 07 SI 823-846 Wilson.pdf.

${ }^{51}$ L. Sossin, 'Experience the Future of Legal Education', (2013) $\bar{C} L P E$ OHLS Research Paper No. 47/2013 http://ssrn.com/abstract=2337521.

${ }^{52}$ H. Dedek/A. de Mestral, "Born to be Wild': The 'Trans-systemic' Programme at McGill and the DeNationalization of Legal Education', (2009) 10 German Law Journal 889-911; R. Jukier, 'Challenging the Existing Paradigm: How to Transnationalize the Legal Curriculum', (2006) 24 Penn State International Law Review 775786; P. B. Bevans/J. S. McKay, 'The Association of Transnational Law Schools' Agora: An Experiment in Graduate Legal Pedagogy', (2009) 10 German Law Journal 929-958

[http://germanlawjournal.com/pdfs/Vol10No07/PDF_Vol_10_No_07_SI_929-958_Bevans_McKay.pdf]

${ }^{53} \mathrm{G}$. Standing, The Precariat. The New Dangerous Class (Bloomsbury, 2011); see, in this vein, R. Sennett, The Culture of the New Capitalism (Yale University Press, 2006).

54 P. Zumbansen, 'Law's Effectiveness and Law's Knowledge: Reflections from Legal Sociology and Legal Theory', (2009) 10 German Law Journal 417-438; M. Thornton, 'The Law School, the Market, and the New Knowledge Economy', (2009) 10 German Law Journal 641-668

[http://germanlawjournal.com/pdfs/Vol10No07/PDF_Vol_10_No_07_SI_641-668_Thornton.pdf].

${ }^{5} \mathrm{H}$. W. Arthurs, 'Law and Learning in an Era of Globalization', (2009) 10 German Law Journal 629-640

[http://germanlawjournal.com/pdfs/Vol10No07/PDF_Vol_10_No_07_SI_629-640_Arthurs.pdf]

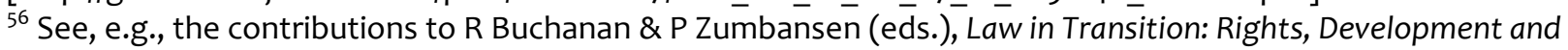

Transitional Justice [with an epilogue by Bryant Garth] (Oxford/Portland: Hart, 2014 - in print).
} 
dimensions that are at the heart of the Settlement? ${ }^{57}$ What will happen is that this "problem" (not case) will perhaps, if at all, be addressed in a new, small seminar on "Transitional Justice". Alternatively, we could imagine it playing a role in courses on "Legal Professionalism", or "Legal Foundations", "Legal Sociology", or, perhaps, "Legal History". In the context of such courses, presumably taught at the start of the increasingly condensed ${ }^{58}$ and simultaneously overburdened legal program, the Settlement will at the least function as an element of providing some historical context for those students aware of these events as well as with an interest in "Aboriginal law", or "Transitional Justice" At best, the Settlement could serve as an illustration of the many complex layers of a problem as they become visible when lawyers attempt to find a legal solution to a deeply ingrained and only very incompletely "worked through" historical experience. ${ }^{59}$

Utopia: Students enrolled in a class on Mediation and ADR would be confronted with a fast growing range of non-commercial, non-corporate legal conflicts that prompt alternative dispute resolution techniques and competences. ${ }^{60}$ Offering an array, say, of fields such as labour $^{61}$, family ${ }^{62}$ or commercial law ${ }^{63}$ disputes along with an example such as the IRSSA could then be used to introduce students to the paradoxical relation between the limits of the law in trying to adequately grasp and address all the dimensions of the IRSSA as they become evident around the TRC proceedings ${ }^{64}$ and wide-ranging public debates on the one hand and the potential for law to push these boundaries and limits in order to make law more receptive and responsive to these overwhelming dimensions on the other. ${ }^{65}$

And, then? In other words, how can this last mentioned utopia be put in relation to the reality of a continuous reluctance of students to engage with law in such unbounded manner, considering an ever greater pressure from the market to leave law school with

\footnotetext{
${ }^{57}$ R. L. Nagy, 'The Scope and Bounds of Transitional Justice and the Canadian Truth and Reconciliation Commission', (2012) 6 International Journal of Transitional Justice 1-22.

${ }^{58} \mathrm{http}$ ://www.insidehighered.com/news/2013/08/26/president-obama-calls-cutting-year-law-school (accessed 21 November 2013).

${ }^{59}$ R. W. Gordon, 'Undoing Historical Injustice', in A. Sarat and T. R. Kearns (eds), Justice and Injustice in Law and Legal Theory (University of Michigan Press, 1999), 35-77; R. M. Buxbaum, 'From Paris to London: The Legal History of European Reparation Claims 1946-1953', (2012) UC Berkeley Public Law Research Paper No. 1914802 http://works.bepress.com/richard_buxbaum/1/.

${ }^{60}$ M. Alberstein, 'ADR and Transitional Justice as Reconstructing the Rule of Law', (2011) Journal of Dispute Resolution http://scholarship.law.missouri.edu/jdr/vol2011/iss1/7/

${ }^{61}$ A. Chagma, 'Alternative Dispute Resolution under Labor Law in Bangladesh', (2012) http://papers.ssrn.com/sol3/papers.cfm?abstract id $=2096949$.

${ }^{62}$ R. H. Mnookin/L. Kornhauser, 'Bargaining in the Shadow of the Law: The Case of Divorce', (1979) 88 Yale Law Journal 950-997; A. J. Cohen, 'The Family, the Market, and ADR', (2011) Journal of Dispute Resolution 91-126.

${ }^{63}$ Y. Dezalay/B. Garth, Dealing in Virtue: International Commercial Arbitration and the Construction of $a$ Transnational Legal Order (Chicago University Press, 1996)

${ }^{64}$ M. James, 'A Carnival of Truth? Ignorance and the Canadian Truth and Reconciliation Commission', (2012) 6 International Journal of Transitional Justice 182.

${ }^{65} \mathrm{H}$. Genn, 'Why the Privatisation of Civil Justice is a Rule of Law Issue', (2012) 36th F.A. Mann Lecture, Lincoln's Inn, 19 November 2012 1-21

(http://www.ucl.ac.uk/laws/academics/profiles/docs/Hazel/36th\%20F\%20A\%20Mann\%2oLecture\%20Website.pdf).
} 
skills, practical competence and an advanced understanding of numerous, highly specialized fields? ${ }^{66}$

\section{The Lawyer: Trained How, Serving Whom?}

Dire job prospects, rising student debt, insufficiently trained graduates for legal practice? What should be the goal of reform in light of these contentions? Legal education reform has long been on the minds of Law School deans, bar associations and judges, while students everywhere are joining the debates as both victims and consumers. ${ }^{67}$ Meanwhile, the logics of the market appear to drive the debate, as the trade-offs between a two- or three-year JD program are weighed against the background of skyrocketed fees and decreased salary expectations. ${ }^{68}$ What is the nature of the problem we are facing? What, in other words, can explain the disconnect between the increased frustration with a market-driven legal education system on the one hand and the growing excitement about law's interdisciplinarity and lawyers' engagement with historians, ethnographers and activists, on the other? If the latter suggests the need to take a closer look at the complexity of law and its explanatory value in a transnationalizing society, how can this be made compatible with a debate around two or three years of legal education? The key to the answer might be found by bringing the aspects of legal theory and legal practice closer together.

In this vein, let us return to some of the other examples offered in the beginning. By now, the here suggested steps of inquiry through the sequence of 1. question, 2. assumption, 3. association, and, 4. utopia is familiar enough to allow us to see that the distance between the first three steps and the latter is indeed much smaller than thought at first. We can already recognize that the established ways of not associating the mentioned non-cases with a particular, neatly circumscribed legal 'field' are intimately tied to a denial of utopia. In other words, it is not that the utopian lawyer pushes against the citadel of a self-assured, parochial doctrinal framework in the name of the yet impossible, unthinkable, out-of-the-

\footnotetext{
${ }^{66}$ Lincoln Caplan, 'An Existential Crisis for Law Schools', New York Times, July 14, 2012, available online at: http://www.nytimes.com/2012/07/15/opinion/sunday/an-existential-crisis-for-law-schools.html? r=0; Paul M. Barrett, 'The Case Against Law School', Bloomberg Business Week, April 1, 2013, available online at: http://www.businessweek.com/articles/2013-04-01/the-case-against-law-school; Eric Posner, 'The Real Problem With Law Schools. They train too many Lawyers‘, SLATE, April 2, 2013, available online at:

http://www.slate.com/articles/news_and_politics/view_from_chicago/2013/04/the_real_problem_with_law_sc hools too many lawyers.html.

${ }^{67}$ See the comprehensive data in the LSSE's 2012 Law School Survey of Student Engagement Report: "Lessons from Law Students on Legal Education", available online at: http://www.Issse.iub.edu/pdf/2012/LSSSE_2012_AnnualReport.pdf (with an intriguing foreword by UC Irvine’s Dean, Erwin Chemerinsky, 'The Benefits of Knowledge', id., at 4 - highligthing the crucial role played by experiential learning as part of law students' education). In this vein, see Sossin, above, note 51. See also L. F. P. Hurtado, 'Transnationalizing Mexican Legal Education: But, What About Students' Expectations?', (2009) 10 German Law Journal 767-782 [http://germanlawjournal.com/pdfs/Vol10No07/PDF_Vol_10_No_07_SI_767782 _Hurtado.pdf].

${ }^{68}$ Daniel B. Rodriguez \& Samuel Estreicher, 'Make Law Schools Earn a Third Year', New York Times, January 17, 2013, available online at: http://www.nytimes.com/2013/01/18/opinion/practicing-law-should-not-mean-living-inbankruptcy.html? $r=1 \&$.
} 
worldish legal imagination. Rather, it is that the line drawing, which is done through the identification of what belongs to a legal 'field' and what falls through the cracks of all legal (doctrinal) fields, denies any such utopia from the start by establishing an entire universe of self-sufficient legal reproduction. ${ }^{69}$ Even if we can well remember how environmental law had to break through the shells of tort law in order to develop legal concepts and instruments that would be adequate to the emerging risk-society, we still tend to treat both 'tort law' and 'environmental law' as legal fields that correspond to a number of courses in any school's curriculum and which, more importantly, capture the ways in which law deals with a particular segment of societal activity and conflict. What fades into the background is the struggle over the stakes of law's engagement with a reality that is never just 'found', but always constructed. Because tort law has a relatively long history in both legal practice and education, it is not often presented to students as the subject of conceptual, let alone political reform. Of course, we all know that "tort law reform" touches on sensitive areas of market organization and power asymmetries in advanced post-industrial societies ${ }^{70}$, but how effective are we really to involve students in the classroom in an engaged reflection on these changing contours of a legal field, which they learn through a cascade of condensed cases and interspersed case-book presentations of "Notes and Questions"? Do we do enough to train our students to feel comfortable in their roles as stakeholders in a continuing debate over the aims and outcomes of legal fields? How can we train them even better to understand tort law 'in context', which means today to include a more than superficial introduction to the changing dimensions of post-industrial, globally integrated markets, the proliferation of expert standard making and the correlating pressure on public oversight, in short: to the realities of globalized market organization today? It would be against this background that students would come to appreciate the stakes involved in imagining, creating and developing a new field - for example, environmental law. While similar contentions can be made for the development of, say, internet law or, more recently, "transitional justice" ${ }^{71}$, the question remains how best to give students even a hint of such challenges during their legal classroom education. How, indeed, could we train students to understand and to assume their roles as 'game changers', as agents of change and critical reflection, when it comes to break down barriers between neatly contained 'fields' of reality control $^{72}$ as well as between such legal fields and different disciplinary demarcations of meaning?

Question: Returning to the example of the tension between the American Supreme Court's struggle with same sex marriage (as well as with federalism, equal protection and standing

\footnotetext{
${ }^{69}$ See, e.g., P. Zumbansen, 'The Politics of Relevance: Law, Translation and Alternative Knowledges', (2013) CLPE OHLS Research Paper No. 45/2013 http://ssrn.com/abstract=2340691.

${ }^{70}$ M. F. Grace/J. T. Leverty, 'How Tort Reform Affects Insurance Markets', (2012) Journal of Law, Economics, \& Organization http://jleo.oxfordjournals.org/content/early/2012/07/24/jleo.ews026.abstract; see already: P. M. Danzon, 'Tort Reform and the Role of Government in Private Insurance Markets', (1984) 13 Journal of Legal Studies 517-549.

${ }^{71}$ See R. Nagy, above note 57.

${ }^{72}$ See the inspiring comments by R. Mani, 'Dilemmas of Expanding Transitional Justice, or Forging the Nexus between Transitional Justice and Development', (2008) 2 International Journal of Transitional Justice 253-265.
} 
of non-state parties to argue the constitutionality of a public statute) and Walmart, a company of Leviathanist dimensions that chooses to create a self-binding norm, we are prompted to ask how the law is to treat this constellation. On its face, the question seems to be about the nature of this self-binding commitment on the part of the company. We ask whether what Walmart does, should be considered as 'law' or, at least, as something comparable to a legal norm. Much seems to speak against it, but perhaps not everything. The fact that Walmart is not a democratically elected body with the authority to create law points to the company's declaration of having no legal significance - at least from a public law perspective. But, what becomes of the allegedly 'private' nature of Walmart, if we take into consideration its far-reaching impact on the employment, financial security, health and welfare of millions of its workers? Echoing longstanding debates ${ }^{73}$ around the foundations and scope of 'corporate social responsibility ${ }^{674}$, Adolf Berle in 1954 already masterfully deconstructed the mythology of corporations ' private nature. ${ }^{75}$ More recently, scholars have continued the investigation into the grey areas between public and private regulation, finding that much of CSR occurs through an interaction between state and market actors. ${ }^{76}$ Recent years have seen the increasing proliferation of private and hybrid - public-private norm generation in areas reaching from environmental self-regulation ${ }^{77}$, accounting ${ }^{78}$ and commercial rule making ${ }^{79}$ to labour law ${ }^{80}$ and corporate governance. ${ }^{81}$ Against this background, what really tells us that Wal-Mart cannot be a "law maker" of sorts? If that were indeed the case, we would possibly have to regard the company's declaration of extending health benefit to same sex partners of its employees as a 'health care measure'. What are the stakes of such a development? The answer seems to depend on the perspective: emphasizing the 'adaption' of a private actor to changes in the law - here in the form of a Supreme Court ruling that does not directly bind the company - would lead us to welcome this act as one of unmandated compliance. Focusing, however, on the legitimacy

\footnotetext{
73 L. D. Brandeis, The Curse of Bigness (Viking, 1934); B. S. Prunty, 'Love and the Business Corporation', (1960) 46 Virginia Law Review 467-476.

${ }^{74}$ For insightful treatments of the history, see, e.g., A. Crane/D. Matten/J. Moon, Corporations and Citizenship (Cambridge University Press, 2008), and J. G. Ruggie, Just Business. Multinational Corporations and Human Rights (Norton, 2013).

${ }^{75}$ A. A. Berle, The 20th Century Capitalist Revolution (Harcourt, Brace \& World, 1954), in particular the chapter on "The City of God".

${ }^{76}$ D. Vogel, 'The Private Regulation of Global Corporate Conduct', in W. Mattli and N. Woods (eds), The Politics of Global Regulation (Cambridge University Press, 2009), 151-188; B. Sheehy, 'Understanding CSR: An Empirical Study of Private Self-Regulation', (2012) 38 Monash Law Review http://works.bepress.com/benedict_sheehy/15/.

77 Sheehy, previous note; E. Meidinger, 'The Administrative Law of Global Private-Public Regulation: the Case of Forestry', (2006) 17 European Journal of International Law 47-87.

${ }^{78}$ D. Kerwer, 'Rules that Many Use: Standards and Global Regulation', (2005) 18 Governance: An International Journal of Policy, Administration, and Institutions 611-632.

${ }^{79}$ G.-P. Calliess, 'Lex Mercatoria: A Reflexive Law Guide To An Autonomous Legal System', in: 2 German Law Journal 17 (1 November 2001) available at: http://www.germanlawjournal.com/article.php?id=109.

${ }^{80} \mathrm{H}$. W. Arthurs, 'Labor Law Without the State', (1996) 46 University of Toronto Law Journal 1-45; K. Kolben, 'Transnational Labor Regulation and the Limits of Governance', (2011) 12 Theoretical Inquiries in Law $403-437$.

${ }^{81}$ P. Zumbansen, 'Neither 'Public' nor 'Private', 'National' nor 'International': Transnational Corporate Governance from a Legal Pluralist Perspective', (2011) 38 Journal of Law \& Society 50-75.
} 
grounds of Walmart's action, we have to remain skeptical about the precarious state of those receiving and the power stance of those who are giving - a grave asymmetry at best. ${ }^{82}$

What a frustrating insight after the initial excitement over a corporate giant that cared to put in place rules which could potentially benefit its employees - and certain of the company's stakeholders, without being legally obligated to do so. The contextualization of such an act, however, revealed that we have to consider the bigger picture of companies that engage in comparable CSR initiatives without at the same time becoming accountable under compliance regimes enforceable by the state. While here, too, much is changing ${ }^{83}$, the trick is to not only acknowledge the fuzzyness of the boundaries separating state and market but, moreover, to complement such conceptual considerations with sustained empirical research and data gathering. ${ }^{84}$ The task, altogether, is to unfold this 'bigger picture' as well as its consequences in the classroom and underscore the conceptual and educational synergies that characterize a well-designed curriculum - one that is based on a thorough engagement with the changes in legal theory and legal practice and the awareness of the crucial role to be played by experiential learning in the context of cuttingedge theory training.

\section{Tracing, Placing Our Footsteps: Cautiously, Boldly}

Assumption: Let us take a few steps back in order to catch our breath, hopefully to become able to gain some historical perspective on the way in which lawyers have been addressing the space between case and "cases" as well as the boundaries between purportedly distinct legal "fields". How far back should we look? Starting in the 1950s, we see a fascinating acceleration of events and concepts. While the European and American post-World War II reconstruction was at first able to cover up, however partially, the deep-running societal conflicts that had plagued rapidly the fast industrializing, militarizing and commercializing

\footnotetext{
${ }^{82}$ In this vein: H. W. Arthurs, 'Private Ordering and Workers' Rights in the Global Economy: Corporate Codes of Conduct as a Regime of Labour Market Regulation', in J. Conaghan, R. M. Fischl and K. Klare (eds), Labour Law in an Era of Globalization. Transformative Practices and Possibilities (Oxford University Press, 2002), 471-487, and A. Blackett, 'Global Governance, Legal Pluralism and the Decentered State: A Labor Law Critique of Codes of Corporate Conduct', (2001) 8 Indiana Journal of Global Legal Studies 401-447.

${ }^{83}$ See, e.g., D. Scheffer/C. Kaeb, 'The Five Levels of CSR Compliance: The Resiliency of Corporate Liability under the Alien Tort Statute and the Case for a Counterattack Strategy in Compliance Theory', (2011) 29 Berkeley Journal of International Law 311-397. See also the European Parliament [EP] Report on 'Corporate Social Responsibility: Accountable, Transparent and Responsible Business Behaviour and Sustainable Growth' of 28 January 2013, available online at: http://www.europarl.europa.eu/sides/getDoc.do?pubRef=//EP//NONSGML+REPORT+A7-2013-0017+0+DOC+PDF+Vo//EN.

${ }^{84}$ Sheehy, above note 76 ; this is emphasized as well by K. W. Abbott/D. Snidal, 'Strengthening International Regulation Through Transnational New Governance: Overcoming the Orchestration Deficit', (2009) 42 Vanderbilt Journal of Transnational Law 501-578, K. W. Abbott, 'Engaging the public and the private in global sustainability governance', (2012) 88 International Affairs 543-564 and by C. Scott, 'Reflexive governance, metaregulation and corporate social responsibility: the 'Heineken effect", in N. Boeger, R. Murray and C. Villiers (eds), Perspectives on Corporate Social Responsibility (Edward Elgar, 2008), 170-185.
} 
Western societies since the late $18^{\text {th }}$ century, ${ }^{85}$ the dream of 'the affluent society' was but short-lived and poignantly discriminatory. ${ }^{86}$ And, yet, during and immediately after events as outrageous as, say, the dark witch hunt conducted by Senator McCarthy, the legal imagination was intrigued by two extremely far-sighted observations. Fortuitously shortcircuiting the worlds of the "domestic" and the "international", Philip Jessup in his Storrs Lectures at Yale Law School alluded to the parallels between the legal organizational and normative character of a large (domestic) business corporation on the one hand and an (international) organization on the other. ${ }^{87}$ He highlighted the fact that large corporations in the economically flourishing Western capitalist world had frequently grown into such enormous proportions that power conflicts between its hundreds of thousands of shareholders and employees and the company's management should really be seen as comparable with the political sovereignty disputes between nation states. Following from this observation, Jessup pointed to the questionable basis on which lawyers tend to readily identify the company as a private, but the international organization as a public entity. Having learned his lesson from the previous decades of legal and social theory's developing interest in empirical data as essential to the legal enterprise ${ }^{88}$, Jessup had good reasons to make a functional argument through which we learn the name and nature of the beast before us. ${ }^{89}$ Be it Tiger, Lion or Dragon (thus, not an animal per se, but a fairy tale creature), they are all dangerous, regardless of their name.

A year earlier, one of American corporate legal theory's poster children ${ }^{90}$, Adolf Berle, penned the already alluded to chapter on the "city of god", in which he depicted the domestic and global dimension of business firms as "quasi-public". The little book, which like Jessup's lectures two years later, were first presented as part of the Storrs Lectures at Yale, met with great interest among social theory informed lawyers and political scientists but fell flat with that strand of the "law and society" surge, which would ultimately prove to be the most successful prodigy: The "law and economics" prairie fire that soon spread around U.S. and eventually Western world law schools and policy making departments ${ }^{91}$, had little

\footnotetext{
${ }^{85}$ See the fascinating portrait of the consequences of this development by the turn of the 19th/20th century in R. Musil, The Man Without Qualities (orig. German, 1921-1941).

86 J.K. Galbraith, The Affluent Society (1958); Brown v. Board of Education, 347 U.S. 483 (1954); J. R. Feagin/B. McNair Barnett, 'Success and Failure: How Systemic Racism Trumped the Brown v. Board of Education Decision', (2004) Illinois Law Review 1099-1130.

87 P. C. Jessup, Transnational Law (Yale University Press, 1956); for a more extensive discussion, see, e.g., C. Tietje/A. Brouder/K. Nowrot, Philip C. Jessup's Transnational Law Revisited (Essays in Transnational Law No.50/2006) 2006), and P. Zumbansen, 'Transnational Law, Evolving', in J. Smits (ed) Elgar Encyclopedia of Comparative Law (2nd ed.) (Edward Elgar, 2012), 898-925 [http://ssrn.com/abstract=1975403].

88 J. Dewey, 'The Historic Background of Corporate Legal Personality', (1926) 35 Yale Law Journal $655-673$.

${ }^{89}$ For a similar argument in adapting modern administrative law to complex societal demands, see J. Willis, 'Three Approaches to Administrative Law: The Judicial, the Conceptual, and the Functional', (1935) 1 UTLJ 53-81. ${ }^{90}$ A. A. Berle/G. C. Means, The Modern Corporation and Private Property [1932]. With a new introduction by Murray Weidenbaum \& Mark Jensen (Transaction Publishers, 1991).

${ }^{91}$ B. R. Cheffins, 'The Trajectory of (Corporate) Law Scholarship', (2004) 63 Cambridge Law Journal 456-506.
} 
sympathies for a "re-embeddedness" of the firm ${ }^{92}$ and for a contextualization of business enterprises in a heavily regulated welfare state. ${ }^{93}$ Instead, the declared goal was one of remembering Hayek's 1944 epistle on 'The Road to Serfdom'94, but to forget Polanyi's 'Great Transformation', written the same year. ${ }^{95}$

Meanwhile, Jessup and Berle are important reminders for a strand in legal thinking that was always acutely aware of the "bigger picture", of the precariousness of a normative order and of the false promises of a legal universe which is constantly being woven and re-woven through abstract principles against ideological smoke-screens, but inherently built on the suppressed or ignored empirical data of a different, conflictual social reality. ${ }^{96}$ The interest jurisprudes in Berlin ${ }^{97}$, the legal realists in New York and California ${ }^{98}$, the legal anthropologists and sociologists in Vienna, Madison, and Cambridge had persistently pointed out the need to empirically ground and test all legal assertions. ${ }^{99}$ But, "law and society" evolved as one thing, while "law and economics" evolved as another, quite another indeed. ${ }^{100}$

Still, and despite all this, our students, burdened with college and graduate school debt and painfully aware of dwindling job opportunities, rightly demand to be well trained. Given the here described background, it is clear that we should give them what they are asking for. But, there is little time, three years on average, maybe less, to train the - critical $^{101}$, skilled ${ }^{102}$,

\footnotetext{
$9^{92}$ See, e.g., C. Williams/P. Zumbansen, 'Introduction: corporate governance after the 'end of history': investigating the new 'great transformation", in C. Williams and P. Zumbansen (eds), The Embedded Firm: Corporate Governance, Labor and Finance Capitalism (Cambridge University Press, 2011), 1-12.

${ }_{93}$ D. Vagts, 'Reforming the 'Modern Corporation': Perspectives from the German', (1966) 80 Harvard Law Review 23-89; K. Pistor, 'Codetermination: A Sociopolitical Model with Governance Externalities', in M. Blair and M. J. Roe (eds), Employees and Corporate Governance (Brookings Institution, 1999), 163-193; J. W. Cioffi, Public Law and Private Power: Corporate Governance Reform in the United States and Germany in an Age of Finance Capitalism (Cornell University Press, 2010).

${ }^{94}$ See also F. A. Hayek, The Mirage of Social Justice [Law, Legislation and Liberty. A new statement of the liberal principles of justice and political economy, vol. 2] (The University of Chicago Press, 1976).

${ }^{95} \mathrm{~K}$. Polanyi, The Great Transformation. The Political and Economic Origins of our Time (Beacon Press, 1944).

${ }^{96}$ D. Campbell, 'The End of Posnerian Law and Economics', (2010) 73 Modern Law Review 305-330; S. Macaulay, 'Relational Contracts Floating on a Sea of Custom? Thoughts about the Ideas of lan Macneil and Lisa Bernstein', (2000) 94 Northwestern University Law Review 775-804; R. C. Ellickson, 'Law and Economics Discovers Social Norms', (1998) 27 Journal of Legal Studies 537-565.

${ }^{97}$ For a recent assessment, see R. Titiriga, 'The 'Jurisprudence of Interests' (Interessenjurisprudenz) from Germany: History, Accomplishments, Evaluation', (2013) 3 International Journal of Law, Language and Discourse 55-78.

${ }^{8}$ J. W. Singer, 'Legal Realism Now', (1988) 76 California Law Review 465-544.

${ }^{99}$ S. E. Merry, 'Anthropology, Law, and Transnational Processes', (1992) 21 Annual Review of Anthropology 357379.

${ }^{100}$ E. Darian-Smith, Laws and Societies in Global Contexts. Contemporary Approaches (Cambridge University Press, 2013).

${ }^{101}$ E. Mertz, The Language of Law School: Learning to "Think Like a Lawyer" (Oxford University Press, 2007).

${ }^{102}$ NITA: 'The Future of Legal Education: A Skills Continuum', White Paper prepared by the National Institute for Trial Advocacy, 20 October 2009, available online at:

http://www.nita.org/resources/docs/Future_of_Legal_Education.pdf.
} 
ethical $^{103}$, and, yes, transnational ${ }^{104}$ - lawyer. Train her how? And, for what? The litany of more than 150 years of legal education reform is not something that today's students are usually aware of, nor would they be very interested, if they were. But, really, why should they? As long as we continue to feed them cases, 'notes and questions', as if most of the law was 'business as usual', spiced infrequently by a shy glance at recent developments, it is unlikely that we can really fruitfully build on and transform the 'case method' - and no one should say we haven't been trying. ${ }^{105}$ So, why should students care, if most of us don't (really, as in 'seriously') care?

In a strange zone of consciousness (and, admittedly, shrewed and ultimately unsatisfying self-rightenousness) one may, at times, dwell in Holmes' iteration that a law student one may still hope to "connect your subject with the universe and catch an echo of the infinite, a glimpse of its unfathomable process, a hint of the universal law". ${ }^{106}$ So, maybe then, one turns to privatize such endeavours and begins to treat them as luxuries that can at best be enjoyed in those (in fact, never coming) quiet, rainy Sunday afternoons, during which the imagination should be nourished so that we may hope to finally inspire the students who have been waiting too long already. Meanwhile, the school's administration recruits once more a "moderator" and "team leader" to guide a largely under-researched brain-storming session on "what is wrong with legal education" (but without the reference to Llewellyn ${ }^{107}$ we might just too quickly believe we 'discovered' this problem). We listen, more or less attentively, and try not to get too distracted by the moderator's irritating use of jargon that, in the end, must fail to sweeten the sour taste of us realizing that sessions like this cannot be the right way to get the 'bigger picture' back into the class room. They are too much focused on "engaging" students but too little on facilitating a discussion among instructors of the larger goals of such engagement. They tend to emphasize the need to use a variety of digital media to make the material more 'accessible' to today's law school audience too much in a self-serving manner, while failing to connect the (good!) idea of the "digital classroom" with the much needed engagement with the deeper concerns regarding decreasing opportunities to read and to discuss in class overarching, systematic and foundational materials. So, it's mostly back to business as usual. The binder with the "materials" from the faculty day on legal education, use of electronics in the classroom and, yes, of course, on ways to internationalize the law school, goes into the shelf, where it shall stay until one fine day. And, all the while, one always finds a few students who are eager to meet for regular explorations of the books and discussions that - let's admit it - first got ourselves excited

\footnotetext{
${ }^{103}$ T. C. W. Farrow, 'Sustainable Professionalism', (2008) 46 Osgoode Hall Law Journal 51-103.

${ }^{104}$ B. Garth, 'Introduction: Taking New Legal Realism to Transnational Issues and Institutions', (2006) 31 Law \& Soc. Inquiry 939-945; Jukier, above note 52; A. Bernstein, 'On Nourishing the Curriculum with a transnational law lagniappe, New York Law School. Public Law and Legal Theory Research Paper Series 06/07', in: available at: http://ssrn.com/abstract=987347; G. Torres, 'Integrating Transnational Legal Perspectives Into the First Year Curriculum', (2005) 23 Penn State International Law Review 801.

${ }^{105}$ K. Llewellyn, Bramble Bush (1928/29) (Oceana Publishing, 1950); M. Moskovitz, 'Beyond the Case Method: It's Time to Teach with Problems', (1992) 42 Journal of Legal Education 241-279.

${ }^{106}$ O. W. J. Holmes, 'The Path of the Law', (1897) 10 Harvard Law Review 457-478, 478.

${ }^{107} \mathrm{~K}$. Llewellyn, 'On What is Wrong With So-Called Legal Education', (1935) 35 Columbia Law Review 651-678.
} 
about the law. Too seldom do such reading circles expand beyond a faculty convenor and students to include other colleagues. Where are they?

What, then, is to become of our excitement over the prospects of possibly doing it all differently, with new knowledge, methods and with fresh energy? What follows after our being intrigued by ideas of teaching the law through Business School-like case studies? Where will we store the newspaper clippings we keep on collecting throughout the semester in the hope to find a good moment to build an entire syllabus around the stories that arise from these snippets? And, what should we do with them?

Case- and problem-oriented legal education, complemented by some basic bigger picture sketching by way of history, theory and political economy, could very well be a promising approach. It could be a way to effectively invite the students to think about what makes a case, in other words, it could be a method of replacing the 'teaching' of four to five cases per class unit by a different kind of instruction.

After presenting the outlines of a typical conflict and its prima facie rendering through a legal lens, we could engage the students in an exercise of unpacking the choice and interpretation of facts that resulted in the legal reconstruction of the original conflict, problem, event. In a next step, we would have to trace the way in which different parties engaged - successfully? - in formulating and mobilizing arguments. Following a (Legal Realist) analysis of what was actually said and conveyed beyond and underneath the words spoken by the parties, we would have to take a step back and appreciate how little of the context in which the 'case' is situated has in fact so far become tangible. Trying to understand the 'time' and the 'place' and 'space' of the case, we are likely to discover previously hidden layers of social interaction, circumstance and coincidences, longstanding practices as well as entrenched positions from which stakeholders operate - which were invisible before. We will be confronted with the problem that our depiction of what is 'relevant' and what isn't is, ultimately, based on choice. The complex nature of understanding a case $\mathrm{e}^{108}$ in this light is only rarely discussed in class. The conclusive depiction of a conflict, dispute or problem in the language of a legal decision has already superseded the underlying choices. ${ }^{109}$ The task for the class room is seems to be to slow down this appropriation of reality by unfolding the space in which a lawyer will actually operate - most often with the goal of never going before court and even less, having to anxiously await "what the courts will do in fact". It is in this sphere between context and case that students will actually have to begin to think like a lawyer, that is, like someone who is in charge of and responsible and accountable for the way in which facts get selected and organized, weighed, highlighted or discarded. In fact, we ought to try to involve them in a discussion which is much more akin to what most of our graduates will do in practice, namely, identify

\footnotetext{
${ }^{108}$ See, e.g., S. Jasanoff, Science at the Bar: Law, Science, and Technology in America (Harvard University Press, 1997).

${ }^{109}$ B. Cardozo, The Nature of the Judicial Process (1921) (Yale University Press, 1976); N. Luhmann, '"Was ist der Fall?" und "Was steckt dahinter?" Die zwei Soziologien und die Gesellschaftstheorie', (1993) 22 Zeitschrift für Soziologie 245-260.
} 
leads, pick out and justify relevant facts, construct a narrative, strategize, and, along the entire way, make hard choices. Reading cases and testing students on holdings and principles is - despite our self-congratulatory claims of how "past" we think Langdell supposedly is - still the way we continue to teach them. Today's curricula are painfully divided between case-method instruction (requiring above all a master-mind in extracting, organizing and administering a maze of new information) and increasing surges in experiential training.

The relevant/irrelevant divide we just identified for cases, and for the cases underneath and around them, in the usual context of law school education, mostly unfolds with view to domestic law. But, the here identified challenge to make students aware of the context in which law separates relevant from irrelevant facts, demarcates between interests and ranks, prioritizes and selects values, presents itself in an even more striking way in the transnational problem-examples we referred to above.

Is the case of the Muslim prayer in Berlin a "domestic" one? Does it have any relevance from a transnational perspective? Would it be helpful for a student (in a German law school) to study this case along with the 2009 referendum in Switzerland over the rights of Muslim religious groups to erect minarets? Is it connected to challenges arising before French courts regarding parents asking their Muslim school children to be exempted from co-educational physical education? What would the course be, in which one could make all these connections? "Transnational constitutional law"? Would the "constitutional law" framework be enough to capture the other dimensions of these cases? In order to understand the legal challenges that arise from increasingly complex, pluralist transnational societies, is it enough to study a series of court decisions from this or that jurisdiction? Would we not have to look at developments going on within social communities in terms of self-organization and positioning? Would we not be advised to study the emergence of religious freedom rights "from the ground up", in order to avoid having to apply yesterday's law to today's changed world? ${ }^{110}$

With a view of the wide-ranging field of transnational human rights litigation ${ }^{111}$, what lessons does the Kiobel case hold for students not enrolled in either "International Human Rights" or "Conflict of Laws"? ${ }^{112}$ Would it be helpful, perhaps even important for First-year students

\footnotetext{
${ }^{110}$ For an introduction of such perspectives, see W. Twining, Human Rights, Southern Voices. Francis Deng, Abdullahi An-Na'im, Yash Ghai and Upendra Baxi (Cambridge University Press, 2009). See also L. Peach, Legislating Morality. Pluralism and Religious Identity in Lawmaking (Oxford University Press, 2002), R. Moon (ed) Law and Religious Pluralism in Canada (University of British Columbia Press, 2008), and A. A. An-Na'im, 'The Compatibility Dialectic: Mediating the Legitimate Coexistence of Islamic Law and State Law', (2010) 73 Modern Law Review 1-29.

${ }^{111}$ C. M. Scott, 'Introduction to Torture as Tort: From Sudan to Canada to Somalia', in C. M. Scott (ed) Torture as Tort (Hart Publishing, 2001), 3-44; P. Zumbansen, 'Beyond Territoriality: The Case of Transnational Human Rights Litigation', (2005) ConWEB Paper 4/2005 at https://www.wiso.unihamburg.de/fileadmin/sowi/politik/governance/ConWeb_Papers/conweb4-2005.pdf.

112 B. Neuborne, 'Some Quick Thoughts on Transnational Human Rights Litigation in American Courts after Kiobel', (2013) NYU Journal of International Law \& Politics Online Forum, 19 April 2013, available online at:
} 
in Tort law to study such a case ${ }^{113}$ What could the effect be of introducing students to the potential use of tort law in such a context? How helpful could it be to draw out the many different legal fields that are in fact at work in cases such as Kiobel? To the degree that we see tort, contract, labor, constitutional law, human rights and conflict of laws at work, where in today's law school curriculum would there be the adequate place to draw out these dimensions so that a graduating student, with an employment in a law firm representing one of the defendants (or, plaintiffs), would know "where to start" when having to advise the senior partner on "what the law is", after the (defendant) client called to seek help "to make this problem go away" viz. the (plaintiff) group stating that they "have tried everything" and don't know what to do now. ${ }^{114}$

Would the solution be a "new" course. A course in what? And where should it be placed in the curriculum? And who should ideally teach the course? Could the solution be "collaborative" teaching? Could it be that teachers in the same area (contracts, torts, crim, property) are asked to sit down together and with international lawyers, human rights activists, advocacy group lawyers etc, to compare and rethink their course programs? Imagine that. Could it be, that professors had to begin to speak to each other? To discuss what they have been doing all along, and how? Could it be that they themselves, not a moderator, had to share their research amongst each other in order to facilitate a real discussion over what is out there and how it can be brought to bear on what we will do in our courses and seminars once the new term rolls around? Could it be, that we have to start coming more often to our office, actually spend time there and eventually run into our colleagues, perhaps even in such a clumsy way in the hallway that we make them drop their papers, one of which might be one they were just reading. We could say: "What are you reading?" And, we could just see the magic unfold from there.

http://nyujilp.org/some-quick-thoughts-on-transnational-human-rights-litigation-in-american-courts-afterkiobel/.

${ }^{113}$ C. M. Scott, 'Translating Torture into Transnational Tort: Conceptual Divides in the Debate on Corporate Accountability for Human Rights Harms', in C. M. Scott (ed) Torture as Tort (Hart Publishing, 2001), 45-63.

${ }^{114}$ R. Meeran, 'Tort Litigation against Multinational Corporations for Violations of Human Rights: An Overview of the Positions Outside the United States', (2011) 3 City University of Hong Kong Law Review 1-41. 